\title{
Expression of tyrosine kinases in human malignancies as potential targets for kinase-specific inhibitors
}

\author{
Christian F Singer*, Gernot Hudelist ${ }^{1 *}$, Wolfgang Lamm, Ruth Mueller, \\ Klaus Czerwenka ${ }^{2}$ and Ernst Kubista
}

\begin{abstract}
Department of Senology and Ludwig Boltzmann-Institute of Clinical Experimental Oncology, University of Vienna, Austria ${ }^{1}$ Department of Obstetrics and Gynecology, Villach Hospital, Villach, Austria

${ }^{2}$ Department of Gynecopathology, Vienna, University of Vienna, Austria

(Requests for offprints should be addressed to C F Singer, Department of Obstetrics and Gynecology, Division of Senology, Vienna Medical University, Waehringer Guertel 18-20, A-1090 Vienna, Austria; Email: christian.singer@meduniwien.ac.at) ${ }^{*}$ (C F Singer and G Hudelist contributed equally to this work)
\end{abstract}

\begin{abstract}
Tyrosine kinase (TK) inhibition has been identified as a promising strategy in the treatment of human malignancies and several synthetic inhibitors have been developed. While the selective blockage of specific TKs is highly effective in vitro, clinical results have been less impressive. It has been suggested that the simultaneous inhibition of multiple TKs might lead to more favorable therapeutic results in vivo. We have therefore performed a systematic analysis of intra-tumoral TK expression in order to identify potential targets for a simultaneous kinase inhibition. To this end, we have analyzed the protein expression of membrane-associated epidermal growth factor receptor (EGF-R), Her-2/neu, platelet-derived growth factor receptor (PDGF-R), insulin-like growth factor receptor (IGF-R), c-Kit and of cytoplasmatic c-Abl in 500 human tumors of epithelial, stromal and mesenchymal origin by immunohistochemistry, and found a distinct pattern of kinase expression: EGF-R, PDGF-R and c-Abl were expressed in the majority of malignant tumors, whereas c-Kit, Her-2/neu and IGF-R protein expression was considerably less frequent. Overall, the EGF-R protein expression was correlated with PDGF-R, c-Kit and c-Abl immunoreactivity $(P=0.003, P=0.001$ and $P<0.001$, respectively). c-Abl was co-expressed with IGF-R and PDGF-R $(P=0.003$ and $P<0.001$, respectively). Kinase coexpression was also seen in tumor subgroups and was particularly significant in breast cancer where IGF-R protein was expressed together with PDGF-R and C-Abl $(P=0.003$ and $P=0.004$, respectively), and in colon cancer where PDGF-R was correlated with EGF-R $(P<0.001)$. With the exception of Her-2/neu expression and age, intra-tumoral TK expression was not associated with parameters such as grading or histological subtypes. Taken together, we have found a specific pattern of kinase co-expression and have identified several potential targets for a tumor-specific multimodal TK inhibition.
\end{abstract}

Endocrine-Related Cancer (2004) 11 861-869

\section{Introduction}

Tyrosine kinase (TK) expression analysis is emerging as an important prognostic tool in the prediction of the clinical course in several human malignancies: the amplification/over-expression of Her-2/neu in invasive breast cancer has been associated with shortened diseasefree survival and overall survival, and thus represents an adverse prognostic parameter (Lohrisch \& Piccart 2001).
Expression of the epidermal growth factor receptor (EGF-R) in prostate cancer is correlated with disease relapse and progression to androgen-independence, and in ovarian malignomas platelet-derived growth factor receptor (PDGF-R) protein expression is a negative prognostic parameter in terms of overall survival (Henriksen et al. 1993, Di Lorenzo et al. 2002).

TKs are also increasingly gaining attention as potential therapeutic targets since a number of synthetic 
TK inhibitors (TKIs) have been developed over recent years and several large clinical trials are currently investigating their use in human solid tumors: gefitinib (ZD1839, Iressa) is a synthetic EGF-R TKI which has been shown to be effective in the treatment of advanced refractory non-small-cell lung cancer with nearly $50 \%$ of patients deriving substantial palliative benefit from gefitinib therapy in one study (Hainsworth et al. 2003). Phase II and III trials of the EGF-R kinase inhibitor erlotinib (OSI-774, Tarceva) are currently underway in patients with advanced non-small-cell lung cancer, ovarian cancer, and head and neck squamous cell cancer (Herbst 2003).

PDGF-R and the TKs c-Kit and Bcr-Abl are targets for the highly specific TKI imatinib (Glivec), and treatment of c-Kit-expressing gastrointestinal stromal tumors and of chronic myeloid leukemia with constitutively activated c-Abl results in impressive clinical responses (Joensuu et al. 2002, Goldman \& Melo 2003).

Unfortunately, although most TKIs are highly effective in vitro, their potential use in vivo is limited to those tumors which express target TKs and in which these kinases also have a role in tumorigenesis. And even then, inhibition of a single TK does not appear to be sufficient to produce a clinically meaningful response. Indeed, until now - with the notable exception of imatinib - most inhibitors have failed to meet the high expectations originally placed on them (Dancey \& Freidlin 2003). The reasons for the disappointing clinical results are largely unknown, but the recruitment of alternative stimulatory pathways and the simultaneous activation of other membrane-bound TKs have been suggested (Normanno et al. 2003). This hypothesis has lead to the evaluation of dual inhibitors of EGF-R and Her-2 (PKI 166, GW 572016, EKB 569) which have been or are being tested in phase I trials (Torrance et al. 2000, Mellinghoff et al. 2002, Bonmi 2003).

In order to identify those human malignancies which most likely profit from such a simultaneous pharmacological TK inhibition, a thorough knowledge of the expression of intra-tumoral TKs is essential. Until now, however, no such comprehensive survey exists. We have therefore used tissue arrays to analyze the protein expression of the six TKs which are believed to play the most significant roles in the progression of a number of human malignancies, and which are potential clinical targets for kinase inhibition (Blume-Jensen \& Hunter 2001). We selected EGF-R, Her-2/neu, PDGF-R, insulinlike growth factor 1 receptor (IGF-1R), c-Abl and c-Kit for their pivotal involvement in a number of solid tumors and for the fact that each of these kinases can be targeted by newly developed, clinically available TKIs (George 2001, Scheijen \& Griffin 2002, Janmaat \& Giaccone 2003,
Camirand \& Pollak 2004). Furthermore, in each case, preclinical studies have already confirmed that these targets can be selectively neutralized by highly specific TKIs. We then investigated potential TK co-expression patterns in order to identify tumor entities that might be particularly vulnerable to combinations of specific TK inhibitors.

\section{Materials and methods Tissue arrays}

Fourth Generation Tissue Arrays (TARP-4) were purchased from the National Cancer Institute Tissue Array Program. Each array contained 500 tissue samples from biopsies obtained from malignant brain tumors (25 samples), malignant breast tumors (75 samples), malignant colon tumors (75 samples), lung cancer ( 75 samples), lymphomas (50 samples), malignant melanomas (25 samples), ovarian cancer (50 samples), prostate cancer (75 samples) and corresponding normal tissues (50 samples). Table 1 shows the mean age, sex and histological classification of the eight tumor subgroups. A detailed listing of these parameters can be viewed for each individual biopsy at http://ccr.cancer.gov/tech_initiatives/tarp.

\section{Immunohistochemistry}

Tissue arrays were de-paraffinized with three washes of xylem for 5 min each, followed by two washes in $100 \%$ ethanol for $10 \mathrm{~min}$ each. The slides were then incubated in two washes of $95 \%$ ethanol for $10 \mathrm{~min}$ and washed in twice in $\mathrm{dH}_{2} \mathrm{O}$ for $5 \mathrm{~min}$. For antigen unmasking, sections were heated in $1 \mathrm{mM}$ EDTA for $10 \mathrm{~min}$. After three washes in $\mathrm{dH}_{2} \mathrm{O}$ for 5 min each, sections were incubated in peroxidase blocking agent $(0.3-1 \%$ hydrogen peroxide) for $5 \mathrm{~min}$ to quench endogenous peroxidase activity and rinsed in PBS for 2 min. The sections were then blocked with serum (dependent on the primary antibody with goat, horse or donkey serum; all from ImmunoCruz Staining System, Santa Cruz Biotechnology, Santa Cruz, CA, USA) for $4 \mathrm{~min}$. After a consecutive PBS wash, slides were incubated with IGF-1R (Ab-1 clone 24-31, mouse monoclonal, 1:100; NeoMarkers, Fremont, CA, USA), EGF-R (clone 31G7, mouse monoclonal, 1:200; Zymed Laboratories, San Francisco, CA, USA), Her-2/neu (Dako A/S, Glostrup, Denmark), PDGF-R- $\alpha$ (C-20, rabbit polyclonal antibody, 1:200; Santa Cruz Biotechnology), c-Abl (no. 2862, rabbit polyclonal antibody, 1:50; Cell Signaling Technology, Beverly, MA, USA) and c-Kit (no. A4502, rabbit polyclonal, 1:100; Dako Cytomation Denmark A/S, Glostrup, Denmark) antibodies for $2-8 \mathrm{~h}$ at room temperature. Negative controls were performed on all tissue arrays by replacing primary 
Table 1 Patient and tumor characteristics.

\begin{tabular}{|c|c|c|c|}
\hline Tumor type & Age \pm S.D. & $\operatorname{Sex}(n)$ & Histology (n) \\
\hline Malignant brain tumor & n.a. & n.a. & Glioblastoma multiforme: 25 \\
\hline Breast cancer & $63.2( \pm 13.7)$ & $\begin{array}{l}\text { Female: } 75 \\
\text { Male: } 0\end{array}$ & $\begin{array}{l}\text { Invasive ductal: } 63 \\
\text { Invasive lobular: } 9 \\
\text { DCIS: } 1 \\
\text { Unknown: } 2\end{array}$ \\
\hline Colon cancer & $67.5( \pm 9.98)$ & $\begin{array}{l}\text { Female: } 30 \\
\text { Male: } 28 \\
\text { Unknown: } 17\end{array}$ & Adenocarcinoma: 75 \\
\hline Lung cancer & $63.7( \pm 10.1)$ & $\begin{array}{l}\text { Female: } 24 \\
\text { Male: } 34 \\
\text { Unknown: } 17\end{array}$ & $\begin{array}{c}\text { Squamous: } 36 \\
\text { Mucinous: } 24 \\
\text { Bronchoalveolar: } 4 \\
\text { Unknown: } 11\end{array}$ \\
\hline Lymphona & $47.1( \pm 25.7)$ & $\begin{array}{l}\text { Female: } 15 \\
\text { Male: } 29 \\
\text { Unknown: } 6\end{array}$ & $\begin{array}{c}\text { Hodgkin lymphoma: } 5 \\
\text { Other: } 45\end{array}$ \\
\hline Melanoma & $51.5( \pm 21.3)$ & $\begin{array}{l}\text { Female: } 8 \\
\text { Male: } 9 \\
\text { Unknown: } 8\end{array}$ & $\begin{array}{l}\text { Primary tumor: } 20 \\
\text { Metastatic: } 5\end{array}$ \\
\hline Ovarian cancer & $62.5( \pm 11.7)$ & $\begin{array}{l}\text { Female: } 50 \\
\text { Male:0 }\end{array}$ & $\begin{array}{l}\text { Serous papillary: } 34 \\
\text { Endometroid: } 5 \\
\text { Mucinous or clear cell: } 11\end{array}$ \\
\hline Prostate cancer & n.a. & $\begin{array}{l}\text { Female: } 0 \\
\text { Male: } 75\end{array}$ & Adenocarcinoma:75 \\
\hline
\end{tabular}

n.a., not available; DCIS, ducted carcinoma in situ.

antibodies with diluted isotype immunoglobulins (ImmunoCruz Staining System). The slides were then incubated with a mouse, rabbit or goat biotinylated secondary antibody provided in the detection kit, and horseradish peroxidase agent for $60 \mathrm{~min}$, and incubated with the substrate chromogen 3,3'-diaminobenzidine for $5 \mathrm{~min}$. Her-2/neu protein expression was determined by using the HercepTest according to the manufacturer's instructions (Dako Cytomation A/S). All sections were counterstained with hematoxylin for $10 \mathrm{~s}$

\section{Immunostaining quantification and statistical analysis}

Protein expression levels were assessed by two experienced pathologists (W L and K C) using the HercepTest in the case of Her-2/neu. A semi-quantitative scoring system (immunoreactive score) was used to allow for a reproducible evaluation of PDGF-R, EGF-R, IGF-1R, c-Abl and c-Kit in immunohistochemically stained tissue sections (Remmele \& Stegner 1987). The immunoreactive score (staining intensity: negative, weak, moderate and strong membranous staining was multiplied by the percentage of positive cells) ranged from 0 to $12 ; 0-2$ points were considered to be negative; weak staining (3-5 points) was defined as $1+$, moderate staining (6-8 points) as $2+$ and strong staining (9-12 points) as $3+$. The SAS
8.2 TS2M0 Win software package was used to perform statistical analyses and $P<0.05$ from a two-tailed test was considered statistically significant.

\section{Results}

\section{TK protein expression in malignant tumors}

Table 2 shows the expression of EGF-R, Her2/neu, PDGF-R, IGF-R, c-Abl and c-Kit in each of the eight tumor entities analyzed. EGF-R was detectable in the cell membrane of tumor cells in all types of malignancies with the most consistent protein expression in brain tumors (64\% of cases), prostate cancer $(52 \%)$ and lung cancer (49\%). EGF-R staining was absent from all of the five Hodgkin lymphomas analyzed, but was present in eight of the 45 non-Hodgkin lymphomas investigated (18\%). In these cases, EGF-R staining was mostly detected in the tumor cells of CD $19(+)$, CD20 (+), CD $5(-)$ and CD 10 (-) lymphomas, although information about the CD expression pattern was not available in all EGF-Rpositive cases. Positive staining in lymphoma cells appeared either as a linear to finely granular pattern in the cell membrane and adjacent cytoplasm, or as a coarsely granular cytoplasmatic staining. A representative picture of an EGF-R-positive tumor (breast cancer) shown in Fig. 1A. c-Abl protein was equally found in all tumor types with expression being predominant in 
Singer et al.: Tyrosine kinases in human malignancies

Table 2 TK receptor protein expression in human malignancies

\begin{tabular}{lcrrrrrr}
\hline Tumor type & Cases & EGF-R & Her-2/neu & PDGF-R & IGF-1R & c-ABL & c-Kit \\
\hline Malignant brain tumor & \multirow{2}{*}{25} & $16 / 25$ & $0 / 24$ & $18 / 22$ & $0 / 24$ & $13 / 22$ & $0 / 25$ \\
& & $(64 \%)$ & $(0 \%)$ & $(82 \%)$ & $(0 \%)$ & $(59 \%)$ & $(0 \%)$ \\
Breast cancer & \multirow{2}{*}{75} & $14 / 69$ & $11 / 68$ & $15 / 64$ & $10 / 68$ & $41 / 71$ & $0 / 69$ \\
& & $(20 \%)$ & $(16 \%)$ & $(23 \%)$ & $(15 \%)$ & $(58 \%)$ & $(0 \%)$ \\
Colon cancer & \multirow{2}{*}{75} & $27 / 69$ & $3 / 68$ & $56 / 75$ & $2 / 68$ & $47 / 72$ & $4 / 72$ \\
& & $(39 \%)$ & $(4 \%)$ & $(75 \%)$ & $(3 \%)$ & $(65 \%)$ & $(6 \%)$ \\
Lung cancer & \multirow{2}{*}{75} & $33 / 67$ & $0 / 63$ & $55 / 65$ & $4 / 61$ & $48 / 69$ & $4 / 67$ \\
& & $(49 \%)$ & $(0 \%)$ & $(85 \%)$ & $(7 \%)$ & $(70 \%)$ & $(6 \%)$ \\
Lymphomas & \multirow{2}{*}{50} & $8 / 50$ & $0 / 48$ & $32 / 46$ & $0 / 50$ & $31 / 46$ & $1 / 49$ \\
& & $(16 \%)$ & $(0 \%)$ & $(70 \%)$ & $(0 \%)$ & $(67 \%)$ & $(2 \%)$ \\
Melanomas & \multirow{2}{*}{25} & $7 / 24$ & $2 / 23$ & $21 / 23$ & $23 / 25$ & $18 / 24$ & $3 / 24$ \\
& & $(29 \%)$ & $(9 \%)$ & $(91 \%)$ & $(92 \%)$ & $(75 \%)$ & $(13 \%)$ \\
Ovarian cancer & \multirow{2}{*}{50} & $7 / 49$ & $4 / 46$ & $29 / 39$ & $1 / 49$ & $20 / 49$ & $0 / 47$ \\
\multirow{2}{*}{ Prostate cancer } & & $(14 \%)$ & $(9 \%)$ & $(74 \%)$ & $(4 \%)$ & $(41 \%)$ & $(0 \%)$ \\
& \multirow{2}{*}{75} & $34 / 65$ & $3 / 67$ & $63 / 65$ & $2 / 67$ & $44 / 68$ & $10 / 68$ \\
& & $(52 \%)$ & $(5 \%)$ & $(97 \%)$ & $(3 \%)$ & $(65 \%)$ & $(15 \%)$ \\
\hline
\end{tabular}

melanomas (75\%), lung cancer $(70 \%)$, lymphomas $(70 \%)$, colon cancer $(65 \%)$ and malignant brain tumors $(59 \%)$. Its expression was detected in the cytoplasm in the majority of tumor cells. A c-Abl-positive malignant breast tumor is shown in Fig. 1E.
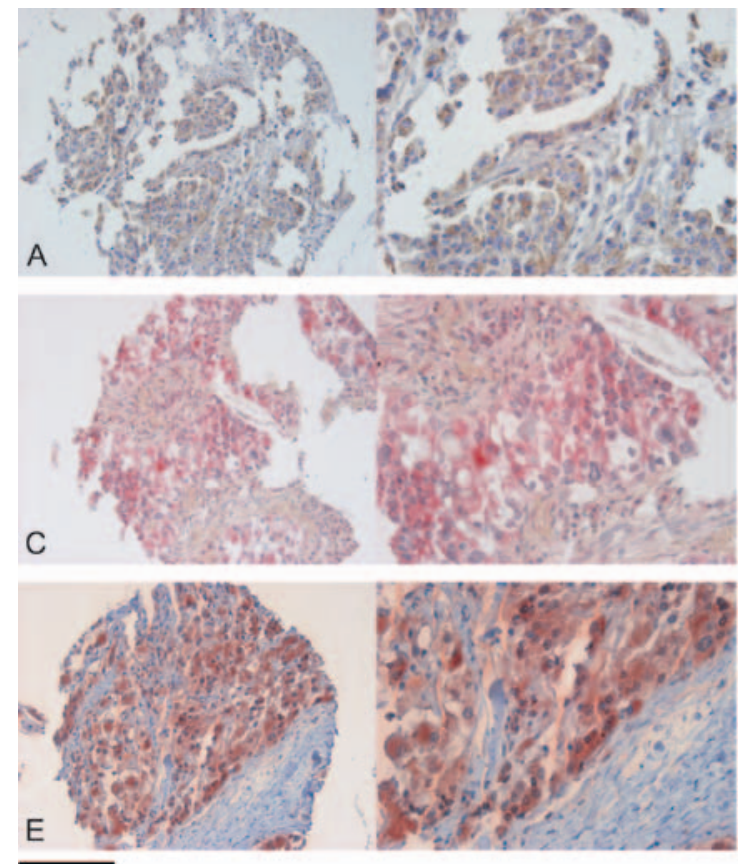

With the exception of breast cancer (23\%), PDGF-R was also immunolocalized in the majority of tumors, regardless of their identity. In the case of prostate cancer and melanomas PDGF-R was even immunodetectable in almost all cases (97 and 91\%, respectively). PDGF-R-

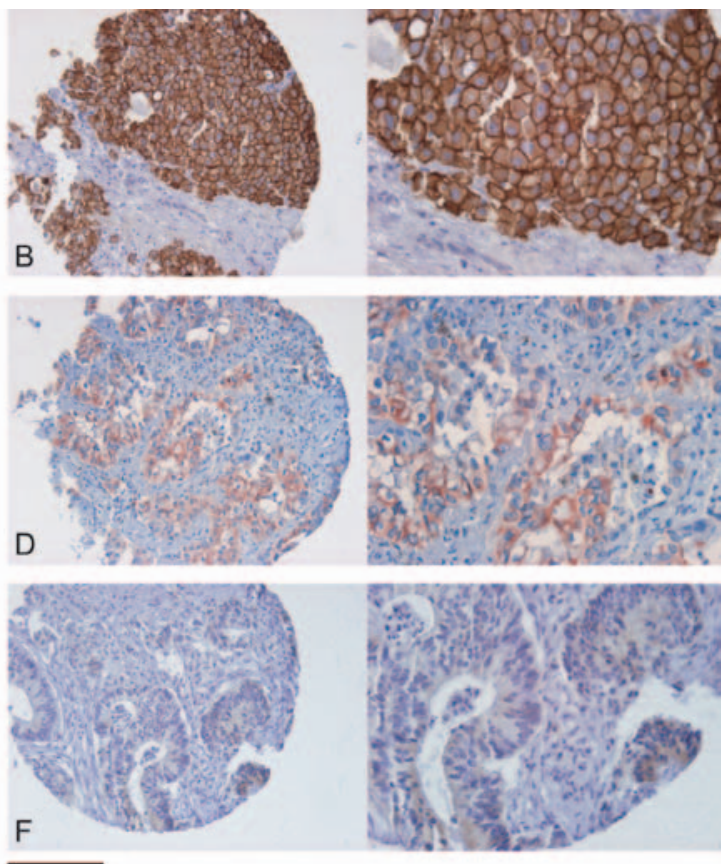

Figure 1 Protein expression of EGF-R, Her-2/neu, PDGF-R, IGF-R, c-Abl and c-Kit in human malignancies by immunohistochemistry. Representative array tissues are shown: (A) EGF-R protein expression (shown in breast cancer tissue); (B) Her-2/neu protein expression (shown in breast cancer); (C) PDGF-R protein expression (shown in a breast cancer sample); (D) IGF-R protein expression (shown in breast cancer tissue); (E) c-Abl protein expression (shown in breast cancer); (F) c-Kit protein expression (shown in a colon cancer sample). All tissues are shown in low-power magnification $(100 \times$, left part of each picture) and in highpower magnification $(\times 300$, right part of each picture). $(A),(C)$ and $(E)$ scale bar represents $0.2 \mathrm{~mm} ;(B),(D)$ and $(F)$ scale bar represents $0.07 \mathrm{~mm}$. 
Table 3 TK receptor protein expression in normal human tissues

\begin{tabular}{|c|c|c|c|c|c|c|c|}
\hline Tissue & Cases & EGF-R & Her-2/neu & PDGF-R & IGF-1R & C-ABL & c-Kit \\
\hline Brain & 3 & $\begin{array}{r}0 / 3 \\
(0 \%)\end{array}$ & $\begin{array}{r}0 / 3 \\
(0 \%)\end{array}$ & $\begin{array}{r}2 / 3 \\
(67 \%)\end{array}$ & $\begin{array}{r}0 / 3 \\
(0 \%)\end{array}$ & $\begin{array}{r}1 / 3 \\
(33 \%)\end{array}$ & $\begin{array}{r}0 / 3 \\
(0 \%)\end{array}$ \\
\hline Breast & 5 & $\begin{array}{r}0 / 5 \\
(0 \%)\end{array}$ & $\begin{array}{r}0 / 5 \\
(0 \%)\end{array}$ & n.a. & $\begin{array}{r}0 / 5 \\
(0 \%)\end{array}$ & n.a. & $\begin{array}{r}0 / 5 \\
(0 \%)\end{array}$ \\
\hline GI tract & 10 & $\begin{array}{r}2 / 10 \\
(20 \%)\end{array}$ & $\begin{array}{r}0 / 9 \\
(0 \%)\end{array}$ & $\begin{array}{r}2 / 10 \\
(20 \%)\end{array}$ & $\begin{array}{l}0 / 10 \\
(0 \%)\end{array}$ & $\begin{array}{r}1 / 8 \\
(13 \%)\end{array}$ & $\begin{array}{l}0 / 10 \\
(0 \%)\end{array}$ \\
\hline Respiratory tract & 5 & $\begin{array}{r}0 / 5 \\
(0 \%)\end{array}$ & $\begin{array}{r}0 / 5 \\
(0 \%)\end{array}$ & $\begin{array}{r}2 / 5 \\
(40 \%)\end{array}$ & $\begin{array}{r}0 / 5 \\
(0 \%)\end{array}$ & $\begin{array}{r}3 / 5 \\
(60 \%)\end{array}$ & $\begin{array}{r}0 / 5 \\
(0 \%)\end{array}$ \\
\hline Lymph nodes & 2 & $\begin{array}{r}0 / 2 \\
(0 \%)\end{array}$ & $\begin{array}{r}0 / 2 \\
(0 \%)\end{array}$ & $\begin{array}{r}0 / 2 \\
(0 \%)\end{array}$ & $\begin{array}{r}0 / 2 \\
(0 \%)\end{array}$ & $\begin{array}{r}0 / 2 \\
(0 \%)\end{array}$ & $\begin{array}{r}0 / 2 \\
(0 \%)\end{array}$ \\
\hline Skin & 2 & $\begin{array}{r}0 / 2 \\
(0 \%)\end{array}$ & $\begin{array}{r}0 / 2 \\
(0 \%)\end{array}$ & $\begin{array}{r}0 / 1 \\
(0 \%)\end{array}$ & $\begin{array}{r}0 / 2 \\
(0 \%)\end{array}$ & $\begin{array}{r}0 / 2 \\
(0 \%)\end{array}$ & $\begin{array}{r}0 / 2 \\
(0 \%)\end{array}$ \\
\hline Reproductive tract & 4 & $\begin{array}{r}1 / 4 \\
(25 \%)\end{array}$ & $\begin{array}{r}0 / 4 \\
(0 \%)\end{array}$ & $\begin{array}{r}0 / 3 \\
(0 \%)\end{array}$ & $\begin{array}{r}0 / 4 \\
(0 \%)\end{array}$ & $\begin{array}{r}0 / 4 \\
(0 \%)\end{array}$ & $\begin{array}{r}0 / 4 \\
(0 \%)\end{array}$ \\
\hline Glandular tissues & 5 & $\begin{array}{r}2 / 5 \\
(40 \%)\end{array}$ & $\begin{array}{r}0 / 5 \\
(0 \%)\end{array}$ & $\begin{array}{r}3 / 5 \\
(50 \%)\end{array}$ & $\begin{array}{r}0 / 5 \\
(0 \%)\end{array}$ & $\begin{array}{r}2 / 5 \\
(40 \%)\end{array}$ & $\begin{array}{r}0 / 5 \\
(0 \%)\end{array}$ \\
\hline Spleen & 2 & $\begin{array}{r}2 / 2 \\
(100 \%)\end{array}$ & $\begin{array}{r}0 / 2 \\
(0 \%)\end{array}$ & $\begin{array}{r}1 / 2 \\
(50 \%)\end{array}$ & $\begin{array}{r}0 / 2 \\
(0 \%)\end{array}$ & $\begin{array}{r}2 / 2 \\
(100 \%)\end{array}$ & $\begin{array}{r}0 / 2 \\
(0 \%)\end{array}$ \\
\hline Urinary tract & 6 & $\begin{array}{r}3 / 6 \\
(50 \%)\end{array}$ & $\begin{array}{r}0 / 6 \\
(0 \%)\end{array}$ & $\begin{array}{r}2 / 5 \\
(40 \%)\end{array}$ & $\begin{array}{r}0 / 5 \\
(0 \%)\end{array}$ & $\begin{array}{r}1 / 5 \\
(20 \%)\end{array}$ & $\begin{array}{r}0 / 6 \\
(0 \%)\end{array}$ \\
\hline
\end{tabular}

Gl tract, gastrointestinal tract.

positive membrane staining is shown in a breast cancer in Fig. 1C. We observed a very different pattern of expression for IGF-R, which was either absent in the case of malignant brain tumors and lymphomas or only present in less than $5 \%$ of samples (colon cancer, ovarian cancer and prostate cancer). Melanomas, however, represent a notable exception with $92 \%$ of tumors being IGF-R-immunopositive. An IGF-R-positive malignant breast tumor is shown in Fig. 1D.

c-Kit protein was absent in all of the malignant brain tumor, breast cancer and ovarian cancer samples and was only present in few tumor tissues in the case of colon cancer, lung cancer, lymphomas, melanomas and prostate cancers. A weakly positive c-Kit-positive colon carcinoma is shown in Fig. 1F. A similar pattern was observed for Her-2/neu: protein expression was immunolocalized in $16 \%$ of malignant breast tumors, $4 \%$ of colon cancer cases, $9 \%$ of melanomas and ovarian cancers, and $5 \%$ of prostate cancers and was absent in all other tumor entities. A representative picture of Her-2/neu protein expression in a malignant breast tumor sample is shown in Fig. 1B.

\section{TK co-expression pattern in different human malignancies}

In order to identify potential interactions between different TKs, we performed a correlation analysis in each of the tumor subgroups. Since immunohistochemical receptor staining was performed on consecutive serial tissue arrays, we were able to evaluate a TK protein expression pattern for each individual tumor biopsy (Table 3). The immunhistochemical TK expression was graded on an ordinal scale as described in the Materials and Methods section.

Overall, EGF-R protein expression was correlated with PDGF-R, c-Kit and c-Abl immunoreactivity ( $P=0.003, P=0.001$ and $P<0.001$, respectively), and c-Abl was co-expressed with IGF-R and PDGF-R ( $P=0.003$ and $P<0.001$, respectively). Using Kendall's tau test, we then analyzed possible TK co-expression pattern within each of the different tumor entities and found that in breast cancer tissue IGF-R was significantly correlated with the expression of c-Abl $(P=0.004$, Kendall's tau) and PDGF-R $(P=0.003$, Kendall's tau). There was a trend towards a statistically significant coexpression of EGF-R and c-Abl protein $(P=0.052$, Kendall's tau), but no such association was observed between EGF-R and PDGF-R, IGF-R, or Her-2/neu protein expression in malignant breast tumors. Similarly, no correlation was detected between c-Abl and PDGF-B or Her-2/neu protein expression, and between Her-2/neu and IGF-R immunostaining.

In colon carcinoma, EGF-R and c-Abl protein expression were highly correlated $(P<0.0001$, Kendall's tau), and there was also a trend towards a co-expression of c-Abl and PDGF-R ( $P=0.055$, Kendall's tau). All other TKs did not exhibit a significant pattern of co-expression when being analyzed by immunohistochemistry. In lung cancer, EGF-R and IGFR ( $P=0.049$, Kendall's tau) were correlated, as well as c-Abl and PDGF-R $(P=0.025$, 
Kendall's tau). Similarly, membrane-associated c-Abl and IGF-R proteins were also found to be associated with each other $(P=0.036$, Kendall's tau).

In lymphomas, only c-Abl and PDGF-R $(P=0.02)$ were significantly co-expressed and we were unable to detect an association in the protein expression of any of the other TKs investigated. While we detected at least a trend towards a statistically significant co-expression of EGF-R and c-Abl $(P=0.056)$, no such observation was made for all other TKs.

Interestingly, a distinct pattern of TK distribution was observed in melanomas, where most TKs were correlated: EGF-R was co-expressed with c-Abl $(P=0.025)$ and cKit $(P=0.031)$, and the immunohistochemical detection of PDGF-R protein was associated with the detection of c-Abl $(P=0.027)$ and c-Kit $(P=0.042)$ protein. Quite similarly, we also noticed a co-expression of EGF-R and $\mathrm{c}-\mathrm{Abl}(P=0.032)$ and of $\mathrm{c}-\mathrm{Abl}$ and PDGF-R $(P=0.023)$ in prostate cancers.

When TK expressions were compared with other histopathological parameters such as patient age, tumor size and grading, we only found a positive correlation between Her-2/neu and age $(P=0.017$, Mann-Whitney test exact $P$ value) in melanomas and a trend towards IGF-R expression and age in ovarian carcinomas $(P=0.051)$. None of the other parameters appeared to predispose for a specific TK expression pattern.

\section{TK protein expression in normal human tissues}

The TK protein expression pattern in an array of 50 normal human tissues is shown in Table 3. None of the TKs investigated was detected in any of the samples obtained from lymph nodes, skin or normal breast tissue (although for technical reasons PDGF-R and c-Abl could not be assessed in breast tissue). Furthermore, out of the four samples derived from the reproductive tract, only one ovarian tissue biopsy stained weakly positive for PDGF$\mathrm{R}$, while all other TKs remained undetectable (Table 3 and results not shown). Interestingly, PDGF-R and c-Abl were selectively expressed in brain tissues and in tissues obtained from the respiratory tract while all other TKs were absent. In the remaining tissues (gastrointestinal tract, glandular tissues, spleen and urinary tract) variable amounts of EGF-R, PDGF-R and c-Abl proteins were expressed, while Her-2/neu, IGF-1R and c-Kit remained undetectable in all cases.

\section{Discussion}

Although we now have an array of potent and highly specific TKIs at our disposal, many compounds have not been able to keep their promise in the treatment of human malignancies. Disappointing clinical trials involving the use of TKIs in several tumor entities have demonstrated that, with the notable exception of imatinib in the treatment of chronic myeloid leukemia and gastrointestinal stromal tumors, and of erlotinib in glioblastomas, the targeting of a single TK does not appear to be sufficient to produce a clinically meaningful response. In principle, several reasons can be held responsible for the apparent lack of efficacy in vivo: (1) the expression of a membraneassociated TK does not necessarily imply that the protein is indeed a key player in pathological processes. It is thus unlikely that neutralization of a non-relevant TK will lead to a selective anti-proliferative response in tumor cells. (2) Most trials involving novel TKIs are set in advanced disease, when tumors are already highly de-differentiated and the development of additional mutations and clonal selection have lead to tumor cells that no longer depend on external signals by TK-specific ligands. It has therefore been suggested to evaluate TKIs in the early (i.e. in the neo-adjuvant) setting rather than in the metastatic phase. Finally, (3) malignant tumors can recruit alternative pathways which, upon blockage of a specific TK, can substitute and circumvent TKI-mediated anti-proliferative effects. In order to avoid these intra-tumoral escape mechanisms, less specific inhibitors such as the pan-Her-2 TKI CI1033 have been developed (Grunwald \& Hidalgo 2003). Another approach might involve the combinatory use of highly specific TKIs which could be customtailored to the TK expression of a malignant tumor (Sridhar et al. 2003).

We have therefore analyzed the co-expression pattern of six TKs, which are believed to have important pathophysiological roles in a number of human malignancies and which can also be effectively neutralized by synthetic TKIs in vitro

We found that the majority of malignant brain tumors express EGF-R, PDGF-R and c-Abl, which would render them potential targets for TK inhibitors such as imatinib, erlotinib or SU-101, which is currently evaluated in phase II and III studies in recurrent glioblastomas and oligoastrocytomas (Vlassenko et al. 2000). Indeed, imatinib has already been evaluated in human glioma cells and has shown to enhance their radio-sensitivity in vivo, thus indicating a key involvement of PDGF-R and possibly also of $\mathrm{c}-\mathrm{Abl}$ in malignant brain tumors (Russell et al. 2003). Recent phase I and phase II studies in patients with gliomas have also shown very promising results with erlotinib, a highly specific EGF-R inhibitor (Prados et al. 2003).

The fact that the inhibition of a single TK leads to a clinically relevant anti-tumoral effect indicates a critical involvement of this kinase in malignant cells. This is possibly the reason for the great success of imatinib-based 
therapies in gastrointestinal stromal tumors and chronic myeloid leukemia, and could also explain the encouraging responses to erlotinib in tumors such as non-small-cell lung cancer, where EGF-R expression has already been identified previously as a negative prognostic parameter (Meert et al. 2002, Miller et al. 2003, Tiseo et al. 2004). Glioblastoma multiforme might be a specifically promising tumor entity for EGF-R TK inhibition, since this subgroup of malignant brain tumors is characterized by a high rate of EGF-R gene amplification and activating mutations. The presence of the receptor variant EGF-RvIII is thus associated with considerably shortened survival, but at the same time renders these tumors specifically interesting targets for EGF-R TK inhibition (Buckner et al. 2004).

It is nevertheless interesting that within a tumor entity, two TKIs that target the same kinase (erlotinib and gefitinib) can still show considerable differences in tumor response. Although we can only speculate, reasons such as patient selection, metabolization or drug dosing might also greatly influence whether a specific TK is successful in vivo (Adis 2003).

In the vast majority of samples from prostate cancer and in lung cancer, we also observed c-Abl and PDGF-R co-expression. In these cases the use of imatinib would again be a suitable therapeutic approach, especially in the light of a recent publication in which imatinib has been shown to exert an additional benefit on the antiproliferative effect of paclitaxel on PDGF-R-expressing prostate tumors in a mouse model (Vehara et al. 2003).

Although the TKs that were expressed most consistently in colon tumors were c-Abl and PDGF-R, the most commonly co-expressed proteins were c-Abl and EGF-R. Consequently, a combination of c-Abl-inhibitory imatinib and EGF-R-blocking gefitinib would appear to be the most effective therapy. This hypothesis is supported by work of Attoub et al. (2002) who found imatinib to be highly effective in the inhibition of colon cancer cell growth in vitro, and by observations of Tortora et al. (2003) who was able to elicit a dramatic cooperative anti-tumoral effect in nude mice bearing human colon cancer xenografts, when adding gefitinib to a combination of a cyclooxygenase- 2 inhibitor and a proteinase $\mathrm{K}$ inhibitor. The latter publication also provides the first demonstration that the three novel agents blocking multiple signaling pathways, in the absence of cytotoxic drugs, may have a potent anti-tumoral and anti-angiogenic activity after oral administration. Unfortunately, until now, no clinical data are available that would confirm these observations.

In contrast to the other malignancies investigated, malignant breast tumors were found to be considerably more heterogeneous in their TK expression pattern and, although variable amounts of c-Abl were expressed in more than $50 \%$ of tumors, the protein expression of other TKs was considerably less frequent in the samples analyzed. Since in breast cancer the c-Abl expression is still significantly correlated with IGF-1R and PDGF-R, a combination of imatinib and an IGF-1R-inhibitory antibody might in principle exert a synergetic effect (Maloney et al. 2003). Nevertheless, the fact that in our samples IGF$1 \mathrm{R}$ is only expressed in $15 \%$ of cases suggests that breast tumors are less likely to be targets for successful TK inhibition.

Our observation of EGF-R, PDGF-R and c-Abl protein expression in a number of normal tissues is neither surprising nor contradictory: several authors have described these TKs in various organs and during different stages of development previously (Maxwell et al. 1998, Nagao et al. 2002, Schmandt et al. 2003, Yano et al. 2003). These findings simply indicate that TKs also have a physiological, tissue-specific role, and that an abrogation of TK-mediated signal transduction can potentially also be associated with undesired side effects. Therefore, a potential benefit, especially in the case of lessspecific synthetic TKIs, will have to be weighed carefully against an unwanted disruption of physiological signaltransduction mechanisms in healthy tissues (Ebnoether et al. 2002, Esmaeli et al. 2002).

Taken together, we have demonstrated the presence of TKs in several human malignancies, and have identified potential targets for a simultaneous TK inhibition. We hypothesize that, with the exception of a few selective tumor entities in which the neutralization of one single receptor is already enough to provide for impressive treatment results, the majority of human malignancies are multi-factorial and therefore the key to successful antineoplastic treatment is the use of a custom-tailored array of several receptor-specific antibodies and kinase inhibitors rather than the sole application of a single TKI.

\section{Acknowledgements}

We would like to thank Dr Ernst Ruecklinger for help with the statistical analyses and Niki Paucz for technical help.

\section{Funding}

This work was supported by grants from Amgen, the Jubilumsfonds der Österreichischen Nationalbank and the Medizinisch wissenschaftlicher Fonds des Bürgermeister der Bundeshauptstadt Wien.

\section{References}

Aldape KD, Ballman K, Furth A, Buckner JC, Giannini C, Burger PC, Scheithauer BW, Jenkins RB \& James CD 2004 
Immunohistochemical detection of EGFRvIII in high malignancy grade astrocytomas and evaluation of prognostic significance. Journal of Neuropathology and Experimental Neurology 63 700-707.

Adis I 2003 Erlotinib: CP 358774, NSC 718781, OSI 774, R 1415. Drugs RD 24 243-248.

Attoub S, Rivat C, Rodrigues S, Van Bocxlaer S, Bedin M, Bruyneel E, Louvet C, Kornprobst M, Andre T, Mareel M, et al. 2002 The c-kit tyrosine kinase inhibitor STI571 for colorectal cancer therapy. Cancer Research 62 4879-4883.

Blume-Jensen P \& Hunter T 2001 Oncogenic kinase signalling. Nature 411 355-365.

Bonomi P 2003 Clinical studies with non-iressa EGFR tyrosine kinase inhibitors. Lung Cancer 41 (Suppl 1) S43-S48.

Camirand A \& Pollak M 2004 Co-targeting IGF-1R and c-kit: synergistic inhibition of proliferation and induction of apoptosis in H 209 small cell lung cancer cells. British Journal of Cancer 90 1825-1829.

Dancey JE \& Freidlin B 2003 Targeting epidermal growth factor receptor are we missing the mark? Lancet 362 62-64.

Di Lorenzo G, Tortora G, D'Armiento FP, De Rosa G, Staibano S, Autorino R, D'Armiento M, De Laurentiis M, De Placido S, Catalano G, et al. 2002 Expression of epidermal growth factor receptor correlates with disease relapse and progression to androgen-independence in human prostate cancer. Clinical Cancer Research 8 3438-3444.

Ebnoether M, Stentoft J, Ford J, Buhl L \& Gratwohl A 2002 Cerebral oedema as a possible complication of treatment with imatinib. Lancet 359 1751-1752.

Esmaeli B, Prieto VG, Butler CE, Kim SK, Ahmadi MA, Kantarjian HM \& Talpaz M 2002 Severe periorbital edema secondary to STI571 (Gleevec). Cancer 95 881-887.

George D 2001 Platelet-derived growth factor receptors: a therapeutic target in solid tumors. Seminars in Oncology 28 (Suppl 17) 27-33.

Goldman JM \& Melo JV 2003 Chronic myeloid leukemia advances in biology and new approaches to treatment. New England Journal of Medicine 349 1451-1464.

Grunwald V \& Hidalgo M 2003 Developing inhibitors of the epidermal growth factor receptor for cancer treatment. Journal of the National Cancer Institute 95 851-867.

Hainsworth JD, Mainwaring MG, Thomas M, Porter LL 3rd, Gian VG, Jones SF \& Greco FA 2003 Gefitinib in the treatment of advanced, refractory non-small-cell lung cancer: results in 124 patients. Clinical Lung Cancer 4 347-355.

Henriksen R, Funa K, Wilander E, Backstrom T, Ridderheim M \& Oberg K 1993 Expression and prognostic significance of platelet-derived growth factor and its receptors in epithelial ovarian neoplasms. Cancer Research 53 4550-4554.

Herbst RS 2003 Erlotinib (Tarceva): an update on the clinical trial program. Seminars in Oncology 30 (Suppl 7) 34-46.

Janmaat ML \& Giaccone G 2003 The epidermal growth factor receptor pathway and its inhibition as anticancer therapy. Drugs of Today (Barcelona) 239 (Suppl C) 61-80.

Joensuu H, Fletcher C, Dimitrijevic S, Silberman S, Roberts P \& Demetri G 2002 Management of malignant gastrointestinal stromal tumours. Lancet Oncology 3 655-664.

Lohrisch C \& Piccart M 2001 HER2/neu as a predictive factor in breast cancer. Clinical Breast Cancer 2 129-135.
Lu C, Speers C, Zhang Y, Xu X, Hill J, Steinbis E, Celestino J, Shen Q, Kim H, Hilsenbeck S, et al. 2003 Effect of epidermal growth factor receptor inhibitor on development of estrogen receptor-negative mammary tumors. Journal of the National Cancer Institute 95 1825-1833.

Maloney EK, McLaughlin JL, Dagdigian NE, Garrett LM, Connors KM, Zhou XM, Blattler WA, Chittenden T \& Singh R 2003 An anti-insulin-like growth factor I receptor antibody that is a potent inhibitor of cancer cell proliferation. Cancer Research 63 5073-5083.

Maxwell M, Galanopoulos T, Neville-Golden J, Hedley-Whyte ET \& Antoniades HN 1998 Cellular localization of PDGF mRNAs in developing human forebrain. Neuropathology and Applied Neurobiology 24 337-345.

Meert AP, Martin B, Delmotte P, Berghmans T, Lafitte JJ, Mascaux C, Paesmans M, Steels E, Verdebout JM \& Sculier JP 2002 The role of EGF-R expression on patient survival in lung cancer: a systematic review with meta-analysis. European Respiratory Journal 20 975-981.

Mellinghoff IK, Tran C \& Sawyers CL 2002 Growth inhibitory effects of the dual ErbB1/ErbB2 tyrosine kinase inhibitor PKI-166 on human prostate cancer xenografts. Cancer Research 62 5254-5259.

Miller VA, Patel J, Shah N, Kris MG, Tyson L, Pizzo M, Zakowski M, Memoli N, Sandler A \& Johnson DH 2003 The epidermal growth factor receptor tyrosine kinase inhibitor erlotinib (OSI-774) shows promising activity in patients with bronchioloalveolar cell carcinoma (BAC): Preliminary results of a phase II trial. Proceedings of the American Society of Clinical Oncology, 35th Annual Meeting, Chicago, IL, USA. Abstract 2491.

Nagao K, Hisatomi H, Hirata H, Yamamoto S, Hikiji K, Yamamoto M \& Kanamaru T 2002 Expression of molecular marker genes in various types of normal tissue: implication for detection of micrometastases. International Journal of Molecular Medicine 10 307-310.

Normanno N, Bianco C, De Luca A, Maiello MR \& Salomon DS 2003 Target-based agents against ErbB receptors and their ligands: a novel approach to cancer treatment. Endocrine-Related Cancer 10 1-21.

Prados M, Chang S, Burton E, Kapadia A, Rabbitt J, Page M, Federoff A, Kelly S \& Fyfe G 2003 Phase I study of OSI-774 alone or with temozolomide in patients with malignant glioma. Proceedings of the American Society of Clinical Oncology, 35th Annual Meeting, Chicago, IL, USA. Abstract 394.

Remmele W \& Stegner HE 1987 Recommendation for uniform definition of an immunoreactive score (IRS) for immunohistochemical estrogen receptor detection (ER-ICA) in breast cancer tissue. Pathologe 8 138-140.

Russell JS, Brady K, Burgan WE, Cerra MA, Oswald KA, Camphausen K \& Tofilon PJ 2003 Gleevec-mediated inhibition of Rad51 expression and enhancement of tumor cell radiosensitivity. Cancer Research 63 7377-7383.

Sawyers CL 2003 Opportunities and challenges in the development of kinase inhibitor therapy for cancer. Genes and Development 17 2998-3010. 
Scheijen B \& Griffin JD 2002 Tyrosine kinase oncogenes in normal hematopoiesis and hematological disease. Oncogene 213 314-333.

Schmandt RE, Broaddus R, Lu KH, Shvartsman H, Thornton A, Malpica A, Sun C, Bodurka DC \& Gershenson DM 2003 Expression of c-ABL, c-KIT, and platelet-derived growth factor receptor-beta in ovarian serous carcinoma and normal ovarian surface epithelium. Cancer 98 758-764.

Sridhar SS, Seymour L \& Shepherd FA 2003 Inhibitors of epidermal-growth-factor receptors: a review of clinical research with a focus on non-small-cell lung cancer. Lancet Oncology 4 397-406.

Tiseo M, Loprevite M \& Ardizzoni A 2004 Epidermal growth factor receptor inhibitors: a new prospective in the treatment of lung cancer. Current Medicinal Chemistry. Anti-Cancer Agents 4 139-148.

Torrance CJ, Jackson PE, Montgomery E, Kinzler KW, Vogelstein B, Wissner A, Nunes M, Frost P \& Discafani CM 2000 Combinatorial chemoprevention of intestinal neoplasia. Nature Medicine 6 1024-1028.

Tortora G, Caputo R, Damiano V, Melisi D, Bianco R, Fontanini G, Veneziani BM, De Placido S, Bianco AR \& Ciardiello F
2003 Combination of a selective cyclooxygenase-2 inhibitor with epidermal growth factor receptor tyrosine kinase inhibitor ZD1839 and protein kinase A antisense causes cooperative antitumor and antiangiogenic effect. Clinical Cancer Research 9 1566-1572.

Uehara H, Kim SJ, Karashima T, Shepherd DL, Fan D, Tsan R, Killion JJ, Logothetis C, Mathew P \& Fidler IJ 2003 Effects of blocking platelet-derived growth factor-receptor signaling in a mouse model of experimental prostate cancer bone metastases. Journal of the National Cancer Institute $\mathbf{9 5}$ 458-470.

Vlassenko AG, Thiessen B, Beattie BJ, Malkin MG \& Blasberg RG 2000 Evaluation of early response to SU101 target-based therapy in patients with recurrent supratentorial malignant gliomas using FDG PET and Gd-DTPA MRI. Journal of Neurooncology 46 249-259.

Yano S, Kondo K, Yamaguchi M, Richmond G, Hutchison M, Wakeling A, Averbuch S \& Wadsworth P 2003 Distribution and function of EGFR in human tissue and the effect of EGFR tyrosine kinase inhibition. Anticancer Research 23 $3639-3650$ 